LEUKAEMIA STEM CELLS

\title{
Homing in on CD44
}

DOI:

10.1038/nrc2019

\section{URLs \\ CD44 \\ http://www.ncbi.nlm.nih.gov/ \\ entrez/query.fcgi?db=gene\&c \\ $\mathrm{md}=$ Retrieve\&dopt=full_ \\ report\&list_uids $=960$ \\ AML \\ http://www.cancer.gov/}

cancertopics/types/leukemia

CML

http://www.cancer.gov/ cancertopics/types/leukemia

\section{BCR}

http://www.ncbi.nlm.nih.gov/ entrez/query.fcgi?db=gene\&c $\mathrm{md}=$ RetrieveEdopt=full_ report\&list_uids $=613$

$\mathrm{ABL}$

http://www.ncbi.nlm.nih.gov/ entrez/query.fcgi?db=gene\&c $\mathrm{md}=$ Retrieve\&dopt=full reportElist_uids $=25<$ http:// www.ncbi.nlm.nih.gov/entrez/ query.fcgi?db=gene\&amp;cmd $=$ Retrieve\&amp;dopt=full reportEamp;list_uids=25>

\section{E-selectin}

http://www.ncbi.nlm.nih.gov/ entrez/query.fcgi?db=gene\&c $\mathrm{md}=$ Retrieve\&dopt=full reportElist_uids $=6401$

L-selectin

http://www.ncbi.nlm.nih.gov/ entrez/query.fcgi?db=gene\&c $\mathrm{md}=$ RetrieveEdopt=full_ reportElist_uids $=6402$

\section{B-ALL}

http://www.cancer.gov/

cancertopics/types/leukemia
Two recent studies have pointed to a key role for the adhesion molecule CD44 in the homing and engraftment of leukaemic stem cells (LSCs), but not normal haematopoietic stem cells (HSCs), in the bone marrow of mice.

In the first study, John Dick and colleagues transplanted human acute myeloid leukaemia (AML) cells into immunocompromised mice, and treated them with a monoclonal antibody (H90) that activates CD44. Treatment with H90 around the time that the AML cells were transplanted reduced engraftment in the mouse bone marrow in a dose-dependent manner. Treatment with $\mathrm{H} 90$ after 3 weeks, once an AML graft was well established, also significantly reduced leukaemic burden. Conversely, the engraftment of normal human cord blood cells transplanted into immunocompromised mice was not affected by $\mathrm{H} 90$.

Why does CD44 activation attenuate AML? The authors showed that treatment with $\mathrm{H} 90$ induces the differentiation of AML cells in vivo, and alters the stem-cell properties of AML LSCs, rendering them incapable of engrafting secondary recipient mice. In addition, $\mathrm{H} 90$ treatment reduced the ability of AML LSCs to home to the bone marrow and spleen. Both of these mechanisms could be involved in the reduction of leukaemic burden by $\mathrm{H} 90$.

In the second study, Rick Van Etten and colleagues found that CD44 is required for the homing and engraftment of chronic myeloid leukaemia (CML) stem cells in bone marrow. Bone marrow from $C d 44^{-/-}$mice transduced with retroviruses containing $B C R-A B L 1$ was defective for homing, engraftment and induction of CML-like disease in wild-type recipient mice compared with transduced marrow from wildtype donors. BCR-ABL increased CD44-dependent haematopoietic cell E-selectin and L-selectin ligands on leukaemic stem cells, and an antibody against CD44 reduced CML-like disease in mice that received $B C R-A B L 1$ transduced $\mathrm{Cd} 44^{+/+}$bone marrow. As in the study by Dick and colleagues, they also found that normal mouse HSCs did not require CD44 to engraft. However, in a model of B-cell acute lymphoblastic leukaemia (B-ALL), CD44 was not necessary for the engraftment of B-ALL-initiating cells.

Although the data from Dick and colleagues indicate that the activation of CD44 can eradicate LSCs by inducing differentiation and preventing them from homing to bone marrow, the data from Van Etten and colleagues suggest that LSC homing is reduced by blocking CD44. Regardless, these studies have identified CD44 as a regulator of LSC, but not normal HSC, function, therefore suggesting that the manipulation of CD44 could be a possibility for AML and CML therapeutics.

Sarah Seton-Rogers

ORIGINAL RESEARCH PAPERS Jin, L., Hope, K. J., Zhai, Q., Smadja-Joffe, F. \& Dick, J. E. Targeting of CD44 eradicates human acute myeloid leukemic stem cells. Nature Med. 24 September 2006 (doi:10.1038/nm1483) | Krause, D. S.,

Lazarides, K., von Andrian, U. H. \& Van Etten, R. A. Requirement for CD44 in homing and engraftment of BCR-ABL-expressing leukemic stem cells. Nature Med. 24 September 2006 (doi:10.1038/nm1489) 